\title{
DECISION ON THE CIVIL EXCEPTION DEVIATES FROM ARTICLE 136 HIR (ANALYSIS OF THE DECISION OF PN SEMARANG NUMBER: 73/Pdt.G/2010/PN.SMG)
}

\author{
Mochammad Dja'is \\ Faculty of Law, Diponegoro University \\ mochammaddjais73@gmail.com
}

\begin{abstract}
Exceptions should be examined and decided along with the subject matter (Article 136 HIR). The Semarang District Court (PN Semarang) has cut a separate exception from the principal issue of the case. The purpose of the study to know whether exactly the decision of PN Semarang. Data were obtained through literature study and participant observation. Based on the qualitative analysis known, the decision of the exception separated from the principal case by PN Semarang is appropriate. The makers of the National Civil Law Procedure should determine, the decision of the exception is left to the judge's discretion.
\end{abstract}

Keywords: decision, exception, principal case

\section{Introduction}

In social life there are often legal disputes. Legal disputes must be resolved through the ordinance and by the institutions provided for it, in order to achieve legal order. This means that a person who feels himself harmed by another person should not act in his own accord. Attempts to recover violated rights, or reinstatement of harassed interests, as well as compensation for damages suffered, should not be exercised through vigilante, because vigilante will lead to mutual retaliation that leads to chaos.

The Civil Law provides a legal dispute resolution pathway, through litigation, dispute resolution alternatives, arbitration or through institutions specifically authorized to resolve civil disputes.

The settlement of legal disputes through litigation is not simple. In practice, every phase of the settlement takes relatively long time, relatively high cost and complicated procedures.

A complicated procedure in the settlement of civil cases through litigation occurs, because to win in a plaintiff or defendant's case other than to have a strong position in the case concerned, must also have legal provisions, in particular, the Civil Procedure Law. 
In the settlement of cases through litigation, the provision of Civil Procedure Law is not merely as a rule of the game, but is a binding provision and must be obeyed. The Defendant can win in court because the plaintiff's lawsuit does not meet the provisions of Civil Procedure Law, for example, a lawsuit is filed with an unofficial court, which the defendant has made as an excuse to file an exception. In this case, the judge will pass the decision on the acceptable exception, and the lawsuit is declared unacceptable.

An exception is one type of answer to the defendant in addition to the basic answer of the case and reconvention. Before deciding on an exception, the judge must check the truth first. The examination of an exception is an examination of matters outside the subject matter of the case. Thus a defendant who was granted his exception becomes the winner in the case, although in fact the principal case of the defendant's position is weak.

In the Civil Procedure Law, unless the exception of an unauthorized judge (declining exception), shall be examined and decided along with the principal case (Article 136 HIR-Herziene Indonesisch Reglement, Revised Indonesian Acts, The Civil Procedure Law for the regions of Java and Madura).

In the civil case Number 73 / Pdt.G / 2010 / PN.SMG at the PN Semarang, the defendant, proposed 3 (three) kinds of exceptions, namely: 1. the formulation of the defendant is not true, 2. the formulation of the plaintiff incorrect, and 3. unclear or vague lawsuits. In the case, the judge has passed the decision to accept all the exception and the claimant's claim is unacceptable.

The decision has been handed down by a judge apart from the principal matter, even dropped before the judge checks the principal matter of the case. Considering that the exception is not an exception of the judge authorized, the judge's decision, in this case, deviates from the provisions of Article 136 HIR.

Accordingly, it is necessary to analyze whether or not the decision on the exception in civil cases No. : 73 / Pdt.G / 2010 / PN.SMG and the judge's actions to examine and decide exceptions (apart from declining exceptions) are separate from the principal issue of the case.

\section{Methods}

Research on DECISION ON THE CIVIL EXCEPTION DEVIATES FROM ARTICLE 136 HIR (ANALYSIS OF THE DECISION OF PN SEMARANG NUMBER: 73/Pdt.G/2010/PN.SMG) is normative legal research.

\section{8}

Diponegoro Law Review, October 2017, Volume 02, Number 02 
Data were obtained through library and field research with document review and participant observation at PN Semarang. Qualitative analysis is conducted to obtain a clear picture about the details of the civil exceptions in PN Semarang.

\section{Theoretical Framework}

\section{a. Understanding and Types of Exception}

An exception is a defendant's refusal to deflect the plaintiff's claim, which does not concern the subject matter, but if it succeeds, it can finish the examination, or frustrate the suit.

Based on this understanding it is known, that the exception is filed by the defendant against the claim of the plaintiff.

In the proposed exception, the defendant may state:

1) The district court is not authorized (incompetent) to examine and adjudicate cases; the authorities are religious courts. In such case the defendant has filed an unauthorized judge exception (declining exception) in absolute competence;

2) The PN Semarang is not authorized to examine and adjudicate cases, the authorities are the PN Menado because the place of silence of the defendant is in Menado. Here the defendant has filed an unauthorized judge exception (declining exception) in a relative competence;

3) The lawsuit has not been filed, because the defendant as the debtor is obliged to pay its debts on December 1, but only on August 25 has been sued. The proposed exception of the defendant, in this case, is dilatoir exceptie (a delayed exception).

4) The case filed in the relevant lawsuit has already been severed by the court, so it cannot be submitted again (one case may not be filed twice). Such a defendant's exceptions are included in the Peremtoir Exception (Premptoire exceptie, an ending exception, decided);

5) The party, whether the plaintiff and / or the defendant has no position as intended in the lawsuit, as the plaintiff sued on behalf of a limited liability company, while not the director, the defendant may file an exception, that the plaintiff has no authority to represent; another example, the defendant was sued when he was not borrowed but his 
brother. This exception is called disqualificatoire exceptie (exceptional exceptions), $\mathrm{R}$ Supomo calls this exception by the term exceptie van gemis aan hoedanigheid. ${ }^{1}$

Including disqualificatoire exceptie is an exception which states the claimant's claim is lacking in the claimant's and / or defendant's behalf, i.e. in the dispute there is a legal subject that has not been included as the plaintiff and / or the defendant.

6) Plaintiff's suit is dark or vague. The so-called exception is an obscure libel exception.

A written lawsuit consist of two parts, namely fundamentum petendi and petitum. Fundamentum petendi contains a description of the events and legal basis of the lawsuit. In outlining events and calling the legal basis of the lawsuit, it must be done clearly and completely. Petitum contains what is required. The formulation of what is required must meet the requirements of light and certainty. If the fundamentum petendi is unclear and incomplete, and / or the petitum is unclear and uncertain, then the suit is obscure libel (dark or vague);

The lawsuit is declared obscure libel by the judge when a lawsuit is filed in writing, not verbally. In the case of a lawsuit filed orally, there may not be an obscure libel lawsuit, since the Head of the Pengadilan Negeri (District Court), as well as the judge, appointed to record the orally filed lawsuit have the ability to formulate the lawsuit under the conditions to be fulfilled. In the case of a lawsuit filed in writing by a Legal Scholar (advocate), in general, the Chairman of the Pengadilan Negeri has never given advice and assistance as mandated by Article 118 HIR and Article 119 HIR. Such practice can be justified, is not a law degree let alone an advocate profession should be experts in preparing the lawsuit. So if the lawsuit does not qualify, it is a professional risk.

7) Plaintiff's lawsuit is groundless or no facts or events support the lawsuit, for example, a lawsuit filed with no legal dispute underlying the lawsuit. In other words between the plaintiff and the defendant, there has never been a legal dispute. Such exceptions are called chicaneus process exceptions (exceptions that state the process of smudging).

Of the seven exceptions, only two types of exception are explicitly regulated in the HIR, namely the exception of unauthorized judges in the absolute competence outlined in

\footnotetext{
${ }^{1}$ R. Supomo. 1958. Hukum Atjara Perdata Pengadilan Negeri. Fasco, Jakarta, hlm. 67; R Supomo, SH. Alm. Cetakan kedua 1972. Hukum Atjara Perdata Pengadilan Negeri. Pradnya Paramita, Jakarta, hlm. 54 290 
Article 134 HIR and the exception of unauthorized judges in relative competence as set out in Article 133 HIR. The other five exceptions are only referred to in broad outline (not clear) in Article 136 HIR which uses the term "in addition to the exception of unauthorized judges."

\section{b. Submission, examination, and decision of exception}

1) Submission of an exception

The arrangements concerning the filing of an exception are found in Article 133 HIR and Article 134 HIR.

In Article 133 HIR specified, the exception of the judge not authorized of a relative competence must be filed before the defendant proposes another denial. If this exception has been preceded by another denial, then the exception must be rejected because the expression is late, even if the exception is true.

In contrast to Article $134 \mathrm{HIR}$, it is determined that the exception of unauthorized judges of absolute competence may be submitted at any time before the decision is made. Even if the defendant did not file such an exception and the court is absolute in the absence of the authority to try the case, then the judge must declare that he/she is not authorized to examine and adjudicate the case concerned.

The different provisions in the two articles can be understood if the underlying reasoning was underlying them. The provisions of the exception under Article 133 HIR are based on the notion that the district court anywhere in the whole of Indonesia is equal, to enforce the same legal provisions. This is in contrast to the provisions of Article 134 HIR governing the absolute competence exceptions. In absolute competence, the courts or litigants are different from the courts or other powers, the law enforced by a single tribunal (e.g., the district court) is different from the law that other courts have to uphold (e.g., religious courts).

In addition to filing an exception, the defendant may also submit the principal answer (answer to the claimant's argument as set forth in the data) and / or reconvention (counter-claim). If there is a reconvention, then the basic answer to the case is called a convention.

In accordance with the principle of concentratie van verweer (the principle of centralizing answers) and the provisions of Article $133 \mathrm{HIR}$, the three types of answers 
shall be submitted at once and in order. This is as the embodiment of the principle of rapid examination.

2) Examination and judge's decision on the exception

With respect to the examination and judgment of judges on the various types of exception, only the exception of unauthorized judges are examined and decided separately from the subject matter, while other exceptions should be examined and decided along with the principal case (Article 136 HIR).

Against this provision, Hapsoro Hadiwidjojjo, a Professor of Law Faculty of Diponegoro University, believes that the provision is impractical and inefficient. According to him, the exceptions should not be examined and disconnected along with the subject matter but left to the judge's discretion. ${ }^{2}$ For this he is given an example, the principal case is complicated, requiring repeatedly (e.g. 20 sessions) examination, while the disqualificatoire exceptie is proved in one trial. In such circumstances, a judge at one time may immediately adjudicate a matter of which: "to accept an exception from the defendant and declare the claimant's claim unacceptable." If followed by the provision of Article 136 HIR, then the judgment of a new judge may be imposed upon completion of examining the principal matter (after carrying out 20 sessions), with the same decision.

Based on this, it is known that the examination of the principal case of the case many times it is useless.

\section{Results and Discussion}

\subsection{Case position}

Some six parents of students through their legal counsel filed a lawsuit against the PN Semarang, registered in the case Number 73 / Pdt.G / 2010 / PN.SMG with defendant RECTOR OF DIPONEGORO UNIVERSITY OF SEMARANG.

The reason for the lawsuit was that, in the eighth semester of January 2010, the children of the plaintiffs who were medical students of Diponegoro University, were unable to

${ }^{2}$ Mochammad Dja'is dan RMJ Koosmargono. 2012. Membaca dan Mengerti HIR. Badan Penerbit Universitas Diponegoro, Semarang, hlm. 107

\section{2}

Diponegoro Law Review, October 2017, Volume 02, Number 02 
perform academic registration because there was no debiting of funds in the savings book for the payment of tuition fees. The Defendant's acts without reference to the existence of the decree constitute unlawful acts, causing both material and immaterial losses to the Plaintiffs;

For the above reasons, the Plaintiffs demanded the Defendants to keep the Plaintiffs' children as Medical Student of Diponegoro University of Semarang and attended the eighthsemester lecture and so on until the decision of permanent legal force, pay compensation and seek confiscation.

Concerning the lawsuit, the Defendant submitted an answer containing an exception, the principal answer of the case (Convention) and the invoice (reconvention).

\subsection{Exception raised by the Defendant}

The proposed exception of the defendant is of two types, namely the disqualificatoire exceptie and the obscure libel exceptions.

a. The disqualificatoire exceptie consist of:

1) The Plaintiff has no standing position

a) In the lawsuit, each parent acts in the interest of his child;

b) that in REALITY, the six children represented by their fathers as students;

c) that according to law living in society, a college student is NOT a student. The word college student is a combination of words: maha and students. According to Kamus Besar Bahasa Indonesia, Second Edition, the fourth print of 1995, page 612, the word maha in front of the students means big. So students mean big students, big words mean not small, in other words, students are not just regular students. Thus a student is a big person or a person who has been able to determine his will without help or represented by others. Regarding the ability to act law, a person who is a student is already capable of legal or adult;

d) that the reasons of the Plaintiffs by appointing the legal circumstances of the students in the form of " the cost of living expenses and tuition fees are the responsibility of their respective parents," NOT REASONS make them status as still immature. A wife who does not work so that all her life needs becomes a dependent of her husband, even residing with her husband her legal status (legal 
status of the wife) is AS ADULT AND CONVENIENTLY WORKING TO DO LEGAL LAW;

e) That for an adult a legal act shall not be represented by a person who holds the authority of a parent or guardian;

f) That because in the letter that mentioned the students are represented by their father, this means that the Plaintiff is wrong in formulating the party. According to the law the lawsuit should be filed by the students themselves (the adults) do not need to be represented by his father;

2) Misrepresent the Defendant

a) whereas in the lawsuit the Defendant states: "RECTOR OF DIPONEGORO UNIVERSITY OF SEMARANG;

b) that the mention of the Defendant is wrong according to law, should the Defendant be an institution (Diponegoro University) not an official (Rector), because in this case the Rector acts as the head of the institution, thereby all his actions are for and on behalf of and legitimate representing the institutions of Diponegoro University;

b. Obscure libel exception

1) that each parent as a Plaintiff acts in two positions, acting for oneself and acting for the benefit of his son, thus according to the law the number of plaintiffs is 12 , but in the description of the fundamentum petendi which is continued in the petitum formula is only called plaintiff totaling 6 (six) persons;

2) that the mention of the inconsistent number of plaintiffs resulted in legal consequences of uncertainty in the number of plaintiffs, resulting in confusion, which in the Civil Procedure Law was referred to as a dark or obscure libel;

\subsection{Legal considerations and the decision of the exception}

The panel of judges consisting of BW CHARLES NDAUMANU, SH. $\mathrm{MH}$ as Chairman, SUGENG HIYANTO, SH. MH and TULUS BASUKI, SH as Members, in their Considerations of the Law principally stated as follows:

a. Considering that the Plaintiffs who "act for themselves" and "act for the benefit of their children" in their respective claims, do not clearly define what legal relationship between the Plaintiff and the Defendant in his capacity "acts for himself" and in what legal

\section{4}

Diponegoro Law Review, October 2017, Volume 02, Number 02 
relationship the Plaintiffs in their capacity ("positions") act in the interest of their children";

b. Considering that in view of the argument underlying the claims in the Plaintiff's lawsuit, the Pengadilan Negeri is of the opinion that there is no legal relationship between the Plaintiffs (the parents) acting for themselves with the Defendants, who have a legal relationship with the Defendant are the plaintiffs in his capacity as a student;

c. Considering that each parent may act on behalf of her children based on a special power of attorney, but the special power of attorney is attached to the reply in the form of a photocopy which can not be shown in the original, so it can not be accepted as a special power of attorney according to law;

d. Considering that Diponegoro University of Semarang is a public legal entity that can perform a legal action, the Rector acts only to represent the legal entity. The Rector is a position within the government bureaucracy, whose decision becomes the responsibility within the scope of the Law of State Administration;

e. Considering, that with the foregoing consideration, the Pengadilan Negeri is of the opinion that the qualified exceptions have been precise and reasonable and hence can be granted;

f. Considering that Diponegoro University as a public legal entity, they can act as a party in a civil case based on legal relationship in civil area;

g. Considering that the Plaintiff's claim is based on an unclear proposition, therefore the lawsuit is an obscure libel;

h. Considering that based on the foregoing considerations, the Pengadilan Negeri is of the opinion that the Defendant's exception to the claim of the Plaintiff's lawsuit is obscure and reasonable, therefore it is also appropriate to be granted;

i. Considering that since the Defendant's exception is granted, the Plaintiff's lawsuit must be declared unacceptable

The legal considerations of the judges may be grouped into two. First, the conception of the exception, the two conclusions are not about the exception. This conclusion facilitates the Panel of Judges in preparing systematic legal considerations of each type of exception filed by the Defendant.

The first group is that the exception filed by the Defendant is of two types, namely the disqualificatoire exceptie (consisting of the Plaintiff having no position of representing and 
incorrectly referring to the Defendant) and the obscure libel exception. Based on this, the Panel of Judges states that the qualified exceptions have been precise and reasonable and therefore can be granted.

Furthermore, the obscure libel exception is considered by the Assembly that the Plaintiffs' claims are not supported by a clear description in the fundamentum petendi, resulting in an obscure libel. Therefore, the Defendant's exception has been justified. Therefore it is also appropriate to be granted.

The second group, in the form of a conclusion not about the exception. Here the Panel of Judges gives consideration that Diponegoro University as a public legal entity can be a party in a civil case if based on legal relations in the field of civilization. It is further said that in the argument of the Plaintiffs' claim does not clearly define the civil law relationship between the Plaintiffs and the Diponegoro University, either in its position of acting for itself or acting for the benefit of the child ".

The legal considerations of the Panel of Judges are not merely indicating the formulation of the Plaintiff's lawsuit is unclear, but it also leads to another matter, namely the absolute competence of the courts. According to the Panel of Judges, that Diponegoro University as a public legal entity can be a party in civil cases if based on legal relations in the civil area, then the dispute that appears to be the absolute competence of the district court. Conversely, if the relationship between students with Diponegoro University is a relationship as a student of students with Diponegoro University as a manager and educational provider, then here Rector as an official acting in the government bureaucracy, whose decision becomes the responsibility in the scope of the Law of State Administration. This becomes the absolute competence of the State Administrative Court.

When examined, all the considerations of the Panel of Judges concerning the aforementioned exceptions are not in violation of or contrary to the applicable law. Thus, the legal considerations of the Panel of Judges as the basis for the judgment of civil cases Number: 73 / Pdt.G / 2010 / PN.SMG at the PN Semarang is appropriate and justifiable. 


\subsection{The judges' decision}

Judge ruling in civil case Number: 73 / Pdt.G / 2010 / PN. SMG was adjudged after several hearings. In the first trial when Plaintiff and Defendant arrived, the Panel of Judges tried to reconcile for it was agreed upon through mediation and appointed RONIUS, SH, the judge of PN Semarang as mediator. In the mediation is not achieved peace, then the second hearing to read the lawsuit, and give the Defendant the opportunity to propose Answers. In the third trial, the Defendant submitted an answer containing, exception (disqualificatoire exceptie and obscure libel exception), convention and reconvention. Continued fourth session about repliek and fifth for dupliek. In both the answer and the duplicate, the Defendant requests the Panel of Judges to immediately disconnect the exception without examining the principal matter first, since the exception truth can be known by reading the lawsuit, whereas the principal issue requires repeated examination. The Defendant's petition was granted by the Panel of Judges, and the hearing was adjourned with the agenda of dropping the interlocutory decision on the Defendant's exception.

In the subsequent session, the Panel of Judges passed the decision to accept the exception of the disqualificatoire and obscure libel filed by the Defendant and declared the Plaintiff's lawsuit unacceptable (niet ontvankelijk verklaard). In relation to this matter, then the original decision is planned as an interlocutory decision, turned into a final decision.

In this case, the Panel of Judges has passed a decision on the exceptions of disqualificatoire and obscure libel separate from the subject matter and dropped before the principal examination of the case. This is not in line with the provisions of Article $136 \mathrm{HIR}$ requiring an exception (other than an exception of unauthorized judges) to be examined and terminated along with the principal issue of the case.

According to Supomo, the purpose of Article 136 HIR is to avoid unnecessary slowness or contrived to make the process run long. In the case of an exception, the case has been decided (the perception of the remedy) and the exceptions should not be terminated immediately, the judge wastes no time. Supomo's opinion is supported by BPH Hapsoro Hadiwijoyo stating that the provisions of Article 136 HIR are impractical and inefficient. ${ }^{3}$

Based on this matter, it is found out that the Panel of Judges of PN Semarang who decides civil case Number: 73 / Pdt.G / 2010 / PN.SMG containing accept the exception of

\footnotetext{
${ }^{3}$ Op. cit. hlm. 107
} 
disqualification and obscure libel separately or without examining the principal of the case can be justified. The Panel of Judges is able to escape from futile actions that cost, time and energy are not small.

\section{Conclusion}

1. The legal considerations of the Panel of Judges as the basis of judges in the judgment of civil cases Number: 73 / Pdt.G / 2010 / PN.SMG to the PN Semarang is justifiable.

2. The Panel of Judges of the PN Semarang who decides civil cases Number: 73 / Pdt.G / 2010 / PN.SMG containing accept the exception of disqualificatoire and obscure libel separately or without examining the principal of the case may be justified.

\section{Recommendations}

It is recommended to the makers of the coming National Civil Procedure Law, to eliminate provisions requiring the judge to examine and adjudicate exceptions along with the principal issue of the case.

\section{References}

Departemen Pendidikan dan Kebudayaan. Edisi Kedua, Cetakan keempat. 1995. Kamus Besar Bahasa Indonesia. Balai Pustaka, Jakarta

Dja'is, Mochammad, 2011. Teknik Mengajukan Eksepsi Dalam Perkara Perdata. Blog Kompasiana, Hukum, diunggah 17 July 2011

Dja'is, Mochammad dan RMJ Koosmargono. 2012. Membaca dan mengerti HIR. Badan Penerbit Universitas Diponegoro, Semarang.

Hugenholtz W. Bewerkt door W.H. Heemskerk. Elfde druk 1976. Hoofdlijnen van Nederlands Burgerlijk Procesrecht. Vugaboekeriij.

Mertokusumo, Sudikno. 1988. Hukum Acara Perdata Indonesia. Liberty, Yogyakarta

Prodjodikoro, Wirjono. 1975. Hukum Acara perdata di Indonesia. Sumur Bandung, Bandung

Subekti. 1989. Hukum Acara Perdata. Binacipta, Jakarta

Supomo. 1958. Hukum Acara Perdata Pengadilan Negeri. Fasco, Jakarta

---------- 1972. Hukum Acara Perdata Pengadilan Negeri. Pradnya Paramita, Jakarta.

\section{8}

Diponegoro Law Review, October 2017, Volume 02, Number 02 
Decision on The Civil Exception Deviates from Article 136 HIR (Analysis The Decision of PN Semarang Number : 73/Pdt.G/2010/PN.SMG)

Sutanto, Retnowulan dan Iskandar Oeripkartawinata. 1989. Hukum Acara Perdata Dalam Teori dan Praktik. Mandar Maju, Bandung. 